\author{
Research Article \\ www.ijrap.net (ISSN:2229-3566)
}

\title{
EFFICACY OF SEEDS OF UTANGAN (BLEPHARIS EDULIS), LAJJAWANTI (MIMOSA PUDICA), VASTUK (CHENOPODIUM ALBUM) IN SHUKRA DUSHTI WITH SPECIAL REFERENCE TO MALE INFERTILITY \\ Govind Prasad Gupta ${ }^{1}$, Chitra Singh ${ }^{2 *}$, Madhu Singh ${ }^{3}$
}

${ }^{1}$ Professor, Department of Rog nidan, Dr. Sarvepalli Radhakrishnan Rajasthan Ayurved University, Jodhpur, India

${ }^{2}$ Assistant Professor, Department of Pharmacology, Rama Medical College Hospital \& Research Centre, Hapur, India

${ }^{3}$ Assistant Professor, Department of Rog nidan, Bundelkhand Government Ayurvedic College, Jhansi, India

Received on: 01/08/21 Accepted on: 05/09/21

\author{
*Corresponding author \\ E-mail: singh11chits@gmail.com
}

DOI: $\mathbf{1 0 . 7 8 9 7 / 2 2 7 7 - 4 3 4 3 . 1 2 0 5 1 3 8}$

\begin{abstract}
The population of the world is increasing day by day but today 1 out of 10 couples is suffering from infertility. There are many reasons for infertility but oligospermia is a major factor of infertility. In Ayurveda, eight kinds of shukra dushti explained, in which ksheen shukra can be considered as oligospermia. Many treatment modules have been depicted in ayurvedic text. In the present study three drugs Lajjawanti, Vastuk and uttangan used for treatment. In this study, 30 patients were selected according to the sign and symptoms described in our texts and semen analysis was done as laboratory investigation. Significant results are found on symptoms like Swinngatrta (body sweating), Sharm (fatigue) Pandutav (anaemia) etc. This drug also showed a dramatic effect on, sperm motility, Viability, Erection and Ejaculation.
\end{abstract}

Keywords: Shukra dushti, ksheen shukra, oligospermia

\section{INTRODUCTION}

According to Ayurveda, the body is said to be composed of seven dhatus, Ras, Rakt, Mamsa, Meda, Asthi, Majja snd Shukra. Shukra dhatu is the last dhatu to be made after all dhatus in the body. Hence, we can say shukra dhatu is the essence of all the dhatus. It is well spread all through the body. Prajotpadana (Fertility) is the main karma of Shukra dhatu and one of the main artha's to be fulfilled by the individual in his lifespan. Acharya Charaka told that "A man without offspring is like a single tree with single branch ${ }^{1}$.

Vitiated Tridosha (three humours); impaired Agni; Impaired production of Dhatu (Rasa to Shukra) depletion of Soumya Bhava; all these factors impair the Shukra Dhatu. Ayurveda Encompasses this Tridoshaja dushti and explains 8 types of shukra dushti i.e., vaataj pittaj, kaphaj, Raktaj, Granthi, Kunapagandhi, ksheen, mutra purish gandhi ${ }^{2}$. While fertility is an essential ingredient for the survival and continuity of species, not all couples can further their families. So, the problem of infertility finds its place in the recorded history of ancient civilizations. Infertility can complicate even the most intimate relationships. It brings many strains on time, finances, ability to make decisions and even the job.

This study was carried out to correlate the parameters of semen analysis from an Ayurvedic perspective and simultaneously validate the Shukra Pareeksha (semen examination) told in classical Ayurvedic literature.

\section{MATERIALS AND METHODS}

\section{Objectives of the study}

1. To study the concept of etiopathogenesis of shukra dushti concerning male infertility.

3. To study on the clinical efficacy of seeds of Utangan (Blepharis edulis), Lajjawanti (Mimosa pudica), Vastuk (Chenopodium album) in male infertility.

Study Design: It was an open labelled clinical study with pretest and post-test design.

\section{Method of collection of data}

30 patients diagnosed as ksheen Shukra/ Oligospermia were selected from IPD/OPD of the National Institute of Ayurveda, Jaipur. A special proforma was prepared with details of history taking, symptoms as mentioned in our classics and allied sciences. Patients were analysed and selected accordingly. Informed consent was taken before participation in the study. The study was carried out as per the international conference of Harmonization-Good Clinical Practices Guidelines (ICH-GCP) or as per the Declaration of Helsinki guidelines.

\section{Inclusion Criteria}

1) male patients between the age group of 22 years to 45 years

2) Patients with a sperm count less than 20 million $/ \mathrm{ml}$

\section{Exclusion Criteria}

1) Male patients below 20 years and above 50 years

2) Patients with Absolute Azoospermia.

3) Patients with major systemic disorders like Tuberculosis, AIDS and STD 


\section{Grading}

\begin{tabular}{|l|l|}
\hline Erection & Ejaculation \\
No erection by any method - 0 & No ejaculation at all - 0 \\
Erection by artificial methods- 1 & Delayed ejaculation without orgasm- 1 \\
Erection but unable to penetrate- 2 & Ejaculation before penetration - 2 \\
Initially difficult but able to penetrate-3 & Ejaculation with penetration - 3 \\
Erection with occasional failure- 4 & Ejaculation with own satisfaction - 4 \\
Erection whenever desire - 5 & Ejaculation with own and partners satisfaction - 5 \\
\hline Sexual desire & Orgasm \\
No desire at all -0 & No enjoyment -0 \\
Lack of the desire -1 & Lack of enjoyment - 1 \\
Desire but no activity -2 & Enjoyment in $25 \%$ of sexual intima- 2 \\
Desire only on demand of partner -3 & Enjoyment in $50 \%$ of sexual intima- 3 \\
Normal desire -4 & \\
Excess desire -5 & \\
\hline
\end{tabular}

\section{Semen analysis}

Some parameters measured in a semen analysis are well established and their reference values have remained stable over time such as:

- volume

$\cdot \mathrm{pH}$

- minimal concentration of spermatozoa and minimum absolute number of spermatozoa per ejaculate

- minimal motility

- maximal leucocyte concentration tolerance

\section{Reference values of semen variables}

- Volume - $2.0 \mathrm{ml}$ or more

- $\mathrm{pH}-7.2$ or more

- Sperm concentration - 20 million spermatozoa/ml or more

- Total sperm count - 40 million spermatozoa or more

- Motility - $50 \%$ or more motile.

- Vitality - $75 \%$ or more life

- White blood cells Fewer than 10 million/ml

\section{Administration of drug}

Utangan seed (Blepharis edulis), Lajjawanti seed (Mimosa pudica), Vastuk seed (Chenopodium album)

Selected patients were made to use the combined powders of Utangan seed, Lajwanti seed and Vastuk seed.

Drug Manufacture - The entire process of drug manufacturing was completed under the supervision of Researchers. First,
Lajwanti Beej, Utangan Beej and Vaastuka Beej were purified by removing the impurities from them. The above-mentioned medicinal seeds were self-dried. After that their powder was made in the pasteurizer. Drugs were used for 45 days for selected patients for research. Each patient was given 3 grams of aushadha yoga in the morning and the evening with milk. During the time of taking the drug, the patient was told to take a digestible food diet.

Follow up: Follow up will be done every after 15 days.

\section{Statistical analysis}

Data were analysed by using statistical software Primer of Biostatistics. Measurements were expressed as means and standard deviations for continuous variables and percentages for categorical variables and were analysed. Paired T-Test and $\mathrm{Z}$ test were used as a test of significance in the inferential statistics. Pvalue less than 0.05 was considered statistically Significant

\section{OBSERVATIONS AND RESULTS}

Table 1: Relief in main symptoms

\begin{tabular}{|c|c|c|c|}
\hline Symptoms & BT \% & AT \% & Relief \% \\
\hline Erection & 37.5 & 85.7 & 93.33 \\
\hline Ejaculation & 30 & 80 & 93.56 \\
\hline Sexual desire & 32 & 89 & 94.9 \\
\hline
\end{tabular}

BT: Before Treatment, AT: After Treatment

Table 2: Relief in associated symptoms

\begin{tabular}{|c|c|c|c|c|c|}
\hline Symptoms & \multicolumn{2}{|c|}{ BT } & \multicolumn{2}{c|}{ AT } & Relief \% \\
\hline & Patients & $\%$ & Patients & $\%$ & \\
\hline Daurbalya & 17 & 56.66 & 7 & 23.33 & 58.83 \\
\hline Mukhshosha & 17 & 56.66 & 2 & 6.66 & 88.23 \\
\hline Pandutav & 18 & 60 & 8 & 26.66 & 55.55 \\
\hline Swinngatrata & 27 & 90 & 6 & 20 & 77.77 \\
\hline Shram & 26 & 86.66 & 10 & 33.33 & 61.53 \\
\hline Shishinvedna & 6 & 20 & 4 & 13.33 & 33.33 \\
\hline Vrishanvedna & 11 & 36.66 & 5 & 16.66 & 54.54 \\
\hline
\end{tabular}

BT: Before Treatment, AT: After Treatment

Table 3: Relief in laboratory investigations

\begin{tabular}{|c|c|c|c|c|c|}
\hline Investigation & \multicolumn{2}{|c|}{ BT } & \multicolumn{2}{c|}{ AT } & Relief $\%$ \\
\hline & Patients & $\%$ & Patients & $\%$ & \\
\hline Sperm Viability & 30 & 58.1 & 30 & 75 & 39.08 \\
\hline Sperm Motility & 30 & 37.5 & 30 & 52.5 & 56.99 \\
\hline Sperm Counting & 30 & 38.56 & 30 & 48.4 & 52.40 \\
\hline
\end{tabular}

BT: Before Treatment, AT: After Treatment 


\section{DISCUSSIONS}

In Ayurveda, male infertility is called as Shandhatva or napunsakta. It is the inability to sire a progeny by a man. Acharya Charaka mentioned four causes that lead to Shandhatva. These include Bija upghaat, dhwaj upghaat, Vriddhavastha (old age), Shukra kshay ${ }^{3}$. When Shukra dhatu is vitiated bt vata and pitta dosh, it affects the quality and quantity of shukra dhatu and ultimately leads to ksheen shukra. Ksheen shukra can be considered as oligospermia. A very big population is suffering from infertility due to oligospermia. The present study gave significant results on Ksheen shukra (oligospermia). Churna of these medicines given a dramatic effect on shukradushti. Lajjawanti (Mimosa pudica) is also proved for increasing the testosterone level in the body ${ }^{4}$. Aphrodisiac activity in males is proved for uttangan (Blepharis edulis) ${ }^{5}$. It is proved in many studies that Vastuk (Chenopodium album) has a good effect on erectile dysfunction in males ${ }^{6-8}$

\begin{tabular}{|c|c|c|c|c|c|}
\hline & Mean & S.D. & S.E. & $\mathrm{t}$ & $\mathrm{P}$ \\
\hline Erection & 93.56 & 13.70 & 2.99 & 20.976 & $<0.001$ \\
\hline Ejaculation & 93.33 & 19.19 & 4.40 & 15.90 & $<0.001$ \\
\hline Serial desire & 94.92 & 17.36 & 3.70 & 21.15 & $<0.001$ \\
\hline Sperm count & 52.40 & 7.00 & 1.30 & 1.30 & $>0.10$ \\
\hline Sperm motility & 56.99 & 9.11 & 1.69 & 10.95 & $<0.001$ \\
\hline
\end{tabular}

\section{CONCLUSION}

Infertility is said failure conception after one year of isolated sex. Male infertility accounts for $50 \%$ of human infertility and is considered less complicated than female. In the present study drug lajjawanti (Mimosa pudica) contains ymimosine alkaloid and mucilage, so it has the good property of shukrajanan (spermatogenesis). Drug Uttangan (Blepharitis edulis) contains olintayn and blepherin glucosides, so it has shukrjanak (spermatogenic) and kamottejak (aphrodisiac) effects. treatment based on Ayurvedic principles was found to be effective in male oligospermia in improving sperm count, sperm motility, sperm viability along with some associated symptoms like Shram, swinngatrata and pandutav.

\section{Recommendation}

We recommend larger and more rigorous studies such as randomised control trials to get more conclusive results.

\section{REFERENCES}

1. Shukla AV, Tripathi R, Charaka Samhita of Agnivesh Revised by Charaka Acharya, Uttarardha, Chaukhamba Sanskrit Pratisthana, Varanasi, Chikitsa sthana, Vajikaran Adhyaya, Chapter 2/1, Verse 16-17. Varanasi: 2009 ed.; p. 49.

2. Acharya Sushruta, Sushruta Samhita, Nibandha Sangrahateeka of Dalhana, edited by Vaidya Yadavji
Trikamji Acharya, Chaukhamba Krishnadas Academy, Varanasi, reprint 2004 Sharira Sthana; Chapter 2, verse 4 p. 824.

3. Shastri PK, Chaturvedi G, Charaka Samhita of Agnivesh Revised by Charka acharya, Uttarardha, Chaukhambha Bharati Academy, Varanasi, Chikitsa sthana, Chapter 30, Verse 154, p 863, 1995 ed.; p. 863

4. Pande M, Pathak A, Aphrodisiac activity of Mimosa pudica, International J Pharm Science Nanotechnology. 2009;2(1): 477-486.

5. Pathak A, Investigation of the aphrodisiac potential of Blepharis edulis, International Journal of Chemical Technology 2009;1(3):769-779.

6. Pande M, Effect on sexual erectile dysfunction, Biomedical Pharmacological Journal 2008; 1: 325-332.

7. Sharma AP, Dravya Gun Vigyan, Chaukhambha Bharati Academy, 2006, p 749.

8. Sharma AP, Dravya Gun Vigyan, Chaukhambha Bharati Academy, 2006, p 571.

\section{Cite this article as:}

Govind Prasad Gupta et al. Efficacy of seeds of Utangan (Blepharis edulis), Lajjawanti (Mimosa pudica), Vastuk (Chenopodium album) in Shukra dushti with special reference to male infertility. Int. J. Res. Ayurveda Pharm. 2021;12(5):35-37 http://dx.doi.org/10.7897/2277-4343.1205138 